\title{
Oskar Szwabowski
}

Uniwersytet Szczeciński

E-MAIL: o.szwabowski@gmail.com

\section{Jak trafiłem na terapię. Z życia w obozie z kości słoniowej}

Ofiarom

\section{STRESZCZENIE}

Autor, przy pomocy autoetnografii, przedstawia kilka obrazów z życia akademickiego, które rozkładają wspólnotę i są irytacyjnodajne. Stara się ukazać atmosferę, która uniemożliwia rozwój myśli krytycznej i społecznie zaangażowanej postawy. Jednocześnie, poprzez odniesienie do koncepcji obozu zawartej w dziełach Agambena oraz stanu wyjątkowego i suwerena z pisma Schmitta, wprowadza metaforę „obozu z kości słoniowej” jako specyficznej formy upodmiotowienia pracowników oraz realnych form władzy, które skrywają się czy to pod formalną demokracją akademicką, czy postulatami wspólnoty, czy „koleżeńskich układów”. „Obóz jest przestrzenią, która otwiera się, gdy stan wyjątkowy zaczyna stawać się regułą" (Agamben, 2008, s. 230). Funkcjonowanie uniwersytetu jako obozu z kości słoniowej skutecznie blokuje pojawienie się boskiego gniewu, który mógłby wypełnić obozowiczów. Podkreślanie destrukcyjnych tendencji w akademii wyrasta z troski o niespełnioną obietnicę przyjaźni, jak i z opowiedzenia się za krytyczną, zaangażowaną funkcją nauki i uniwersytetu.

SŁOWA KLUCZOWE: stan wyjątkowy, uniwersytet, autoetnografia, homo sacer.

\section{W chwili obecnej wolałbym nie być odrobinę rozsądnym}

(Melville, 2009, s. 36)

TELEGRAM PIERWSZY

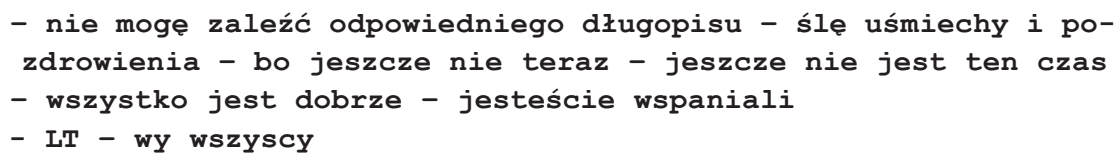

\section{Dobre rady dla początkujących}

Za każde słowo trzeba płacić. Z reguły według obowiązujących taryf. Nie znajdziesz ich wywieszonych na tablicy ogłoszeń, lecz skryte pod formalnymi zapisami, szeptane przez starszych kolegów i koleżanki z doświadczeniem. Ten obóz ma swoje regulaminy, mówią, ukryte w dziekańskich szufladach. O zapiskach, szepczą, dowiadujesz się poprzez baczną obserwację: kto prze- 
trwa, kto się utrzymuje, kto awansuje. Tylko ciiii, wiedzę zachowuj dla siebie, bo nigdy nie wiesz, z kim rozmawiasz. Nigdy nie wiesz, czy nie ma włączonego dyktafonu. Posiadanie teczek we własnych szufladach to podstawa. Powinny być grubsze niż wszystkie twoje książki i artykuły razem wzięte.

Uważaj na słowa, uważaj na ruchy. Pamiętaj, nie ma uniwersytetu bez szpiegów. Ich ciche armie spisują słowa i rejestrują gesty. Armie szpiegów szczególnie są niebezpieczne. Wiedzą, że ich moc, ich istnienie, zależy od utrzymywania stanu zagrożenia. Wiedzą, że muszą dostarczać ofiar. Nie mogą pozwolić sobie na bezczynność. Nieustanie, dzień po dniu, godzina po godzinie, w każdej chwili swojego istnienia zmuszeni są dostarczać dowodów - nawet sfabrykowanych. Inaczej straciliby rację istnienia - stoczyliby się do roli innych poddanych. Staliby się tak samo krusi, tak samo podatni na spojrzenie i arbitralną przemoc jak pozostali.

Szpiedzy się maskują za uśmiechami. To jedna z cech pozwalająca ich rozpoznać. Przynajmniej tak można przypuszczać. Lepiej, jeśli chce się przetrwać w obozie, założyć, że tak jest. Uśmiechnięci są niebezpieczni.

Mówią ci: opanuj sztukę obserwacji. Kiedy obserwujesz, to patrz uważnie i naśladuj, szepczą. Gesty, uśmiechy, sposoby poruszania się, wypowiadania. Każdy element jest bardzo istotny. Wystarczy nie taka tonacja, małe uchybienie i... - mówią ci, na to wszystko trzeba bardzo uważać, bardzo uważać. Nie ma innej drogi, jak opanować sztukę pozoru w celu przetrwania. Niezależnie od wszystkiego okazywać sympatię, ale też pogardę dla przyjaciół, gdy staną się niewygodni. Zresztą, nierozsądne jest posiadanie przyjaciół na uniwersytecie.

To podstawowe zasady, które mogą pomóc w przetrwaniu - wyczytanie nienapisanego regulaminu $z$ obozowych rytuałów. Chociaż to nie jest pewne. Nic nie jest pewne i nikt, w przestrzeni obozu.

A pisanie tekstów? Nie jest jednym ze sposobów przetrwania? Moje naiwne pytania. Uśmiechy doświadczonych, kpiące spojrzenia. Nie masz co liczyć, że mogą ciebie ocalić. Ich wartość, tak jak wartość twojego życia, tak jak bycie we wspólnocie, jest zależna od woli suwerena. Jednym słowem może odebrać im wartość lub ją nadać. Punkty są tylko mniej lub bardziej przydatnym wzmocnieniem woli władcy. Nic więcej. Nawet, dodał jeden bardziej odważny, niekiedy mogą przyspieszyć twoją eksterminację, wiesz, gdy na przykład piszesz teksty przez władzę niechciane, kontrowersyjne czy piszesz lepiej, więcej, i takie tam, to... najlepiej to nie pisać za dużo, tyle tylko, by przetrwać ocenę i tak, by nic nie powiedzieć.

Gdy czyta się obozowe wspomnienia, jednym z największych problemów był brak regulaminu. Nie istniały zasady, których przestrzeganie mogłoby 
zagwarantować przetrwanie. Agamben mówi, że w obozie przetrwanie zależy od woli funkcjonariusza, jest się zdanym na jego łaskę i niełaskę - „to, czy wydarzają się okropności, czy nie, nie zależy od prawa, ale wyłącznie od ucywilizowania i zmysłu etycznego policji” (Agamben, 2008, s. 238-239).

Wczoraj rozmawiałem ze strażnikiem X. Żartowaliśmy. Poczęstował mnie nawet papierosem. Dzisiaj wybił mi kolba przednie zęby. Nie zdążłem się nawet przywitać.

Venit mors velociter, rapit nos atrociter

Dekoracje są zmurszałe, a to wymaga coraz większego wysiłku, przekonywania siebie i innych, że są rzeczywistością. Kruchość władzy, wpisana w nią niepewność, potęgowana przez splot neoliberalnych praktyk, ministerialnych eksperymentów i działań różnych stronnictw wewnątrz i na zewnątrz akademii, prowokuje księcia-dziekana, nie-do-końca-suwerena do coraz brutalniejszych manifestacji, mających na celu ukazanie związku między jego wolą a prawem.

Najgorzej jest, gdy nie-do-końca-suweren opuszcza swoje komnaty i schodzi, aby być wśród podwładnych - to nie może skończyć się dobrze. Moment, w którym styka się z powierzchnią nierozróżnialności, jest uzależniony od aury, która chroni ją przed równością. Aury wyblakłej, słabnącej przez rozproszenie władzy w zimnych, zracjonalizowanych pokojach administracji, w beznamiętności urzędników, którzy jedynie wykonują swoją pracę, bez zbytniego szaleństwa, blasku boskości. Zejście, aby nie podkreślało elementu bycia nie-do-końca, musi wzmacniać aurę okrucieństwem. Jest to zejście, w którym wybiera się ofiarę.

Suweren jest zawsze nie-do-końca. Domknięcie, jako konieczna i niemożliwa próba jego przetrwania (Deleuze, 2004, s. 2014), nakazuje mu nieustannie dokonywać cięć w ciele społecznym, manifestowania swojej siły, tak aby nie można było dostrzec pęknięcia, będącego źródłem słabości, nieustannego rozkładu władzy, którą mogliby intensyfikować poprzez swoje praktyki podporządkowani.

A gdy się jeszcze uśmiechnie...

Nie wiem, mówi znajomy, kiedy i z której strony uderzy. Wiem, że uderzy. Wiem to dobrze. Wczoraj się do mnie władza uśmiechała. Nie zdążyłem się schować za rogiem. Nie wiem, nie wiem, jak mogłem być tak nieostrożny.

Nie rozumiem logiki, zgodnie z którą zapadają wyroki.

Nie-do-końca suweren zna różne gry, które współtworzymy.

Nie wiadomo, czy się one odbywają czy nie, ale się mówi 
i niekiedy działamy jakby działały

chociaż nie zawsze

zależy

nie wiadomo od czego

Wydrapane na ścianie:

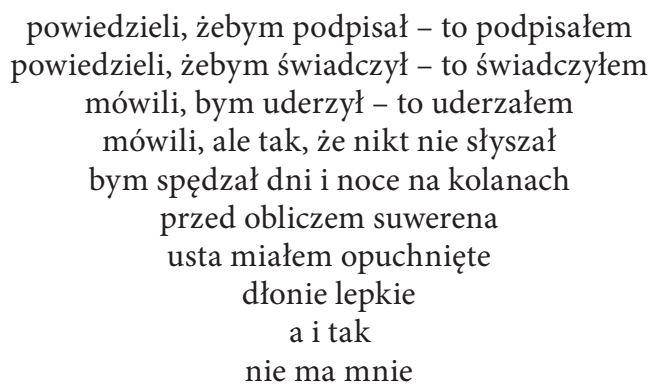

Współczesny akademik, przelękniony perspektywa utraty jedynej pracy, jaka umie dobrze wykonywać, przestaje już być strażnikiem świata; staje się kolejnym trybikiem w gigantycznym mechanizmie prowadzacym ten świat do ruiny. Ten trybik będzie milcząco wykonywał rozkazy, wiedzac, że próba buntu równoznaczna jest dziś z wylądowaniem na bruku (Kruszelnicki, 2012, s. 161).

Jest wiele takich opowieści wydrapanych na ścianach. Świadectwa posłuszeństwa i nieposłuszeństwa, oporu i podległości. Przeróżne strategie zakończone podpisem: „nie ma mnie”. Zostały tylko chropowate zagłębienia w ścianie - dzieło życia.

Tyle opowieści, tyle słów, niewypowiedzianych. Kolega mówi: nie czytaj tego. Nie ma to sensu. Trzeba to przeczekać.

Tyle opowieści, tyle słów, wyszeptanych.

Trzymaj się, rzucamy sobie w marszu, na apelu, gdy ktoś jest wzywany przez oblicze Pana. Trzymaj się, to kiedyś minie, to tymczasowe. Jeszcze będzie dobrze. Musimy to wytrzymać. Musisz to wytrzymać. Na razie nic nie mówić, na razie nic nie czynić. Mówię tobie, wtop się, trzymaj głowę nisko, przytakuj - a jakoś, może, będzie dobrze.

Klepią mnie w ramię - nie jest tak źle. Zobacz: nasze baraki są z kości słoniowej. Zobacz: w innych obozach jest znacznie gorzej. A tam, na horyzoncie, widzisz, jest obóz śmierci dla tych wszystkich zbędnych. Ciesz się, że nie od razu tam trafiłeś.

Ciesz się widokami. 


\section{A może by zniknąć?}

Trzeba nauczyć się być niewidocznym. Siebie, swoją pracę wykonywać $\mathrm{w}$ cieniu, skrytym w bezpiecznym półmroku, schowanym w szczelinach monitorowanej przestrzeni: korytarzy, sal, parkingów... Ukrytym przed indywidualnym, suwerennym spojrzeniem księcia-dziekana i zwielokrotnionym, mechanicznym okiem zimnej administracji.

Naiwne pragnienie. Stawanie się niewidocznym to przecież obraza dla władzy - i największe dla niej zagrożenie. Stawanie się niewidocznym to intensyfikowanie pęknięcia, tego nie-do-końca. To uruchamianie innych sposobów istnienia, innych ujednostkowień (Bey, 2003).

Władza musi widzieć. Widzieć to wiedzieć, widzieć to kontrolować. „Widzialność jest pułapką" (Foucault, 1998, s. 195), w którą wpadamy, w której zostajemy zamknięci. Zarówno przez oko suwerena, jak i jego rozproszone spojrzenia, administracyjne narzędzia corocznych sprawozdań, zeznań, wyznań. Zniknąć można tylko na warunkach suwerena - stając się społecznie, symbolicznie czy w inny sposób martwym.

Nie można zniknąć, mówią koleżanki i koledzy. Musimy napisać sprawozdanie. Oni też funkcjonują na zasadzie stanu wyjątkowego. Reguły gry zmieniają się szybciej niż wykonasz ruch. Poza tym, że nieustannie jesteś obserwowany. Strefa nierozróżnialności otoczona jest murem gęstym od wieżyczek strażniczych i kamer.

Po L został jedynie niedokończony artykuł. Nikt nic nie wie. Jest dobrze. Lepiej być nie mogło.

\section{Gdy zaczniesz słyszeć głosy}

Czuję się coraz bardziej obco. Coraz mniej dopasowany. Element, który się zwichrował. Wyłamał z całości i dla całości okazał się zbędny.

Siedzę w pokoju na uniwersytecie i nie mogę się skoncentrować. Miałem pracować.

Grzecznie pracować. Zamiast tego opisuję to, co powinno zostać ukryte.

Siedzę w pokoju. Mam wrażenie, że jestem we wrogim miejscu.

Nadsłuchuję głosów za drzwiami.

Moja obecność tutaj jest podejrzana.

W pokoju półmrok. Mrok akademii wypiera wiosenne słońce, którego promienie przedostają się przez okienne szyby.

Nadsłuchuję.

Cisza. Szept. Kroki.

Przytłumiona rozmowa, gdzieś, za którą ze ścian, a może piętro wyżej. Nie jestem w stanie zlokalizować. Nie jestem w stanie rozpoznać słów. Mimo to napełniają mnie lękiem. 
Oddycham z trudem. Zdaje się, że w pokoju brakuje powietrza. Mrok uniwersytetu się zagęszcza.

Wraz z nim coraz więcej szeptów.

$$
\begin{gathered}
\text { Brzmią złowrogo. } \\
\text { słowa, kroki - zwiastują, } \\
\text { że to nadejdzie } \\
\text { szepty narastają } \\
\text { pęcznieją } \\
\text { pełzną po ścianie } \\
\text { wraz z cieniami i pleśnią } \\
\text { Stukot obcasów pod drzwiami. } \\
\text { A może to wojskowe oficerki. } \\
\text { Oczekuję pukania do drzwi. }
\end{gathered}
$$

Nic.

Cisza.

Próbuję czytać, ale co chwilę tracę wątek.

Po co tu siedzę? Czy to na pewno moje miejsce? Czy nie trafiłem tutaj przypadkiem?

$\mathrm{W}$ te mury, do tej gry, której nie jestem w stanie zrozumieć.

W końcu odkryją, że nie jestem prawdziwym graczem, że nie uznaję rytuałów.

ukarze się dystynkcja - i to będzie wyrok.

\author{
Nadsłuchuję. \\ Słyszę oddech szpiegów.
}

Ktoś coś znowu powiedział.

Można dostać świra. Te ciągłe kontrole, sprawdzanie, szpiegowanie, tak jakbyśmy nie pracowali. Zaczyna się wariować. To jakaś paranoja.

TELEGRAM DRUGI

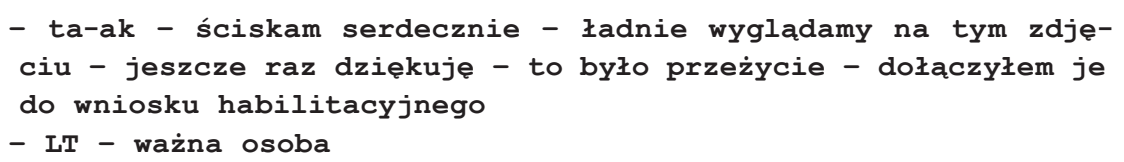

W sklepiku pojawiły się produkty pierwszej potrzeby: Xanax, Nefadar, Depakine, Neuleptil, Morfeo, Halcion

\title{
Nie
}

Od „nie” się nie zaczyna ani się na nim nie kończy. Jest tylko „ta-ak”, tak osła (Deleuze, 2000, s. 35), rozbrzmiewające niczym modlitwa w upadłej świątyni wyznawców antywartości. Ich pełne namaszczenia „ta-ak” jest 
negacją życia, powiewem grobowego, mrocznego nihilizmu, skrywającym się za pozorem.

Rytmiczny marsz podporządkowany maszynom produkcyjnym posłusznych wyrobników. Spętanych w podwójną pętlę: feudalizmu i neoliberalizmu. Dostosować się, przetrwać, wznosić modły, mówić tylko „ta-ak” - jeśli okazywać solidarność, to z władzą, nie z tymi, którzy cierpią, którzy znikają. Nikt nie chce być „znikniętym”. Wszyscy zgodnie śpiewają.

Tak mi się to ponuro totalizuje. Zapominam o ludziach i momentach, które prześwitują wśród ruin, które są epifanią uniwersitas. Zapominam - bo te momenty, ci ludzie są jakby z innego świata. Nie przynależą do porządku obozu z kości słoniowej. Nawiedzają go, niczym zjawy, przypominając o tym, co stracone i przynosząc mesjańską obietnicę, realizującą się w samym spotkaniu - aby po chwili rozwiać się... Ich „nie” jest tak ciche, zagłuszane przez marszowy krok potakiwaczy. Mój śpiew. Zgodny.

Holloway (2005) stwierdza, że poznanie rozpoczyna się od „nie”. Krzyk, niezgoda, uruchamiają krytyczne poznanie. To dzięki „nie” jesteśmy w stanie przejść od indywidualnej, teraźniejszej kondycji, do społecznych uwarunkowań i możliwości zmiany. Bez „nie” nie jest się w stanie rozpoznać sytuacji, nie można rozpocząć drogi do mądrości, która nie jest jedynie erudycją, lecz myśleniem zaangażowanym. Z etyką, z konkretnym działaniem dla lepszego świata.

"Nie” jest na uniwersytecie możliwe jedynie jako słowo-bez-ducha. Nie mogę się oburzać na niesprawiedliwość tu i teraz, w moim mrocznym obozie. Tylko byle nie na obóz. Mogę się oburzać abstrakcyjnie - staję się niewiarygodny, kiedy nie chcę widzieć zła we własnym domu. Moje „nie” nie wymaga wtedy odwagi ani działania. Obojętność, skoncentrowanie na przetrwaniu, udowadnianie dopasowania do panującego porządku - przenika słowa. Stają się one obojętne. Dla mnie, dla świata.

Stają się ta-ak.

Stają się martwe.

Paulo Frerie napisał kiedyś, że słowa łączą ze światem. Z czym łączą nas pseudomowa, cyniczne, puste słowa? Martwe słowa łączą nas z martwą rzeczywistością obozu, z jego pustką, złowroga ciszą - i z karłowatym istnieniem. To nie jest już tylko „potakująca pedagogia” (Kwieciński, 2012, s. 277), która przytakuje władzy poprzez badania. To istnienia, które zawierzyły władzy i które przez władze są utrzymywane.

Suweren jako Jeden-wszystko uruchamia praktyki immunizacji (Esposito, 2015, s. 104), traktując wszystko, co nie stanowi jego ciała, jako wirusy, zagro- 
żenie istnienia. Suweren staje się prawdą, o którą troszczą się, której pożądają, którą odkrywają, którą kontemplują prawdziwi ludzie uniwersytetu.

Pan B zmarł po kilkugodzinnym apelu. W gazecie napisane zostało, że to było serce. Podobno pękło.

Najgorsza z postaw jest obojętność, powiedzenie sobie 'ja nic nie moge, sam staram się sobie radzić'. Zachowują się w ten sposób, pozbawiacie się jednego ze składników, które czyniq was człowiekiem. Jednego ze składników niezbędnych: zdolność do oburzania się i do zaangażowania, które jest jej konsekwencja (Hessel, 2011, s. 15).

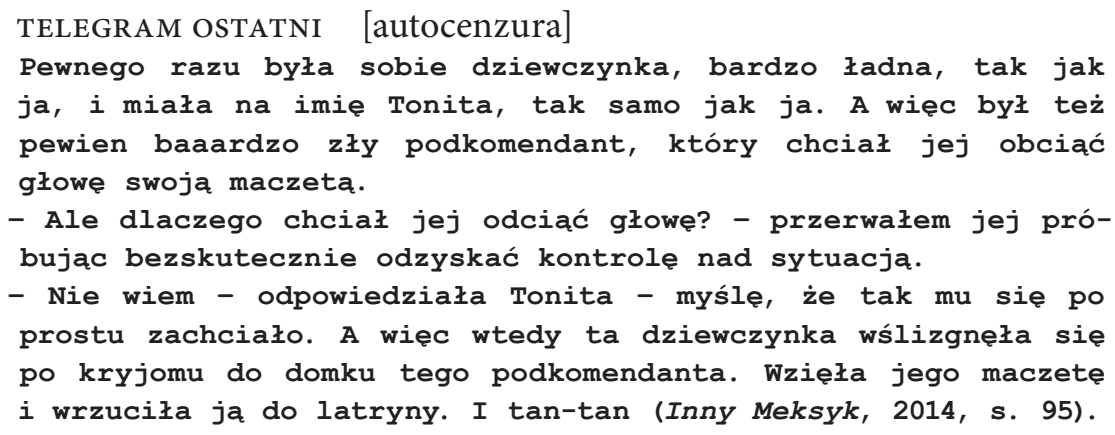

\section{BIBLIOGR AFIA}

Agamben, G. (2008). Homo sacer: suwerenna władza i nagie życie. Przekł. M. Salwa, Warszawa: Prószyński i S-ka.

Bey, H. (2003). Poetycki terroryzm. Przekł. J. Karłowski, Kraków: Der Rumtreiber Stowarzyszenie Tripanacja.

Deleuze, G. (200o). Nietzsche. Przekł. B. Banasiak, Warszawa: „KR”.

Deleuze, G. (2004). Foucault. Przekł. M. Gusin, Wrocław: Wydawnictwo Naukowe Dolnośląskiej Szkoły Wyższej Edukacji TWP.

Deleuze, G. (2014). Spiznoza. Filozofia praktyczna. Przekł. J. Brzeziński, Warszawa: Wydawnictwo Naukowe PWN.

Esposito, R. (2015). Pojęcia polityczne. Wspólnota, immunizacja, biopolityka. Kraków: Universitas.

Foucault, M. (1998). Nadzorować i karać. Narodziny więzienia. Przekł. T. Komendant, Warszawa: Fundacja Aletheia.

Hessel, S. (2011). Czas oburzenia! Przekł. P. Witt, Warszawa: Oficyna Naukowa.

Holloway, J. (2005). Change the World without Taking Power. The Meaning of Revolution Today. London: Ann Arbor, MJ: Pluto Press.

Inny Meksyk: opowieści zapatystów (2014). Poznań: Oficyna Wydawnicza Bractwa „Trojka”.

Kruszelnicki, M. (2012). Bezrobocie albo uległość. Rocznik Pedagogiczny, nr 35.

Kwieciński, Z. (2012). Pedagogie postu: preteksty, konteksty, podteksty. Kraków: Oficyna Wydawnicza „Impuls”.

Melville, H. (2009). Kopista Bartleby. Historia $z$ Wall Street. Przekł. A. Szostkiewicz, Warszawa: Wydawnictwo Sic!. 


\section{SUMMARY}

How I came to therapy. Life in the camp made of ivory

The author, using autoethnography, shows several images of academic life that break the community and are irritating. He tries to show the atmosphere that hinders the development of critical thought and socially committed attitude. At the same time, by reference to the concept of the camp, present in the works of Agamben and the state of exception as well as a sovereign from Schmitt writing, the author introduces the metaphor of "the camp made of ivory", as a specific form of empowerment of employees and real forms of power that are hidden either in a formal academic democracy or community demands or "peer systems." "The camp is the space that opens up when the state of exception starts to become the rule" (Agamben, 2008, p. 230). The functioning of the university as the camp made of ivory effectively blocks the appearance of divine wrath, which could fill the campers. Emphasizing the destructive trends in the academy grew out of concern for the unfulfilled promise of friendship, and the advocate for the critical, involved function of science and the university.

KEY WORDS: the state of exception, university, autoethnography, homo sacer. 